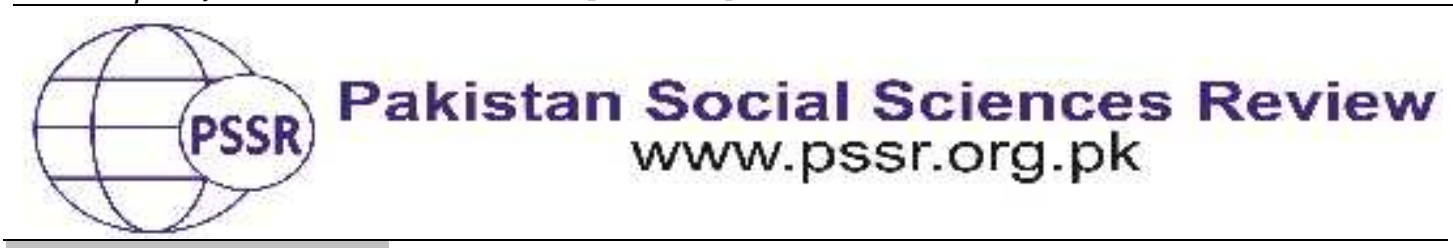

RESEARCH PAPER

\title{
Climate Change: Impacts on Pakistan and Proposed Solutions
}

Fakhara Shahid ${ }^{1}$ Dr. Mubeen Adnan* 2

1. Ph. D. Scholar, Department of Political Science, University of the Punjab, Lahore, Punjab, Pakistan

2. Associate Professor, Department of Political Science, University of the Punjab, Lahore, Punjab, Pakistan

\begin{tabular}{|c|c|}
\hline PAPER INFO & ABSTRACT \\
\hline $\begin{array}{l}\text { Received: } \\
\text { February } 22,2021 \\
\text { Accepted: } \\
\text { May 01, } 2021 \\
\text { Online: } \\
\text { May } 15,2021\end{array}$ & $\begin{array}{l}\text { In recent era the arguments over the climatic variations has } \\
\text { gained momentum. Dangerous impacts caused by these } \\
\text { variations in the climate change have also heated the political } \\
\text { discourses. Using qualitative content analysis approach, it is } \\
\text { found that there is huge difference between facts and values }\end{array}$ \\
\hline $\begin{array}{l}\text { Keywords: } \\
\text { Climate Change, } \\
\text { CONVID-19, } \\
\text { Greenhouse Gasses, } \\
\text { Impacts, } \\
\text { Pakistan }\end{array}$ & $\begin{array}{l}\text { countries. Pakistan being a developing economy already facing } \\
\text { many problems, while catastrophic impacts of climate change } \\
\text { further adding fuel to fire. Due to having agriculture based } \\
\text { economy the impacts of climate change over Pakistan is very }\end{array}$ \\
\hline $\begin{array}{l}\text { *Corresponding } \\
\text { Author }\end{array}$ & $\begin{array}{l}\text { economy, Pakistan along with other world would put measures } \\
\text { to tackle climate change at second priority, a view presented by } \\
\text { pessimists. Communicating strategies along with good } \\
\text { governance would help to minimize the challenges posed by } \\
\text { climate change. }\end{array}$ \\
\hline
\end{tabular}

\section{Introduction}

In this century human race is facing a serious threat in the form of climate change which has undermines the survival of the human civilization. In simplest form climate change is the phenomenon by which the atmospheric changes take place which leads towards alternations in the global eco and bio spheres through slow natural processes. Climate change is caused by natural as well as by men made activities. The dangerous gases (methane, $\mathrm{CO} 2$, and nitrous oxides etc.) is emitted by human beings through various domestic, commercial and industrial activities (IPCC 2014).In recent era the arguments over the climatic variations has gained momentum. Dangerous impacts caused by these variations in the climate change has also heated the political discourses. The depiction, representation, and interpretations along with the catastrophic impacts of the climate change has put our planet in constant danger. There is strong description that due to the hazardous impacts of climate change the likelihood of war will increase due resources scarcity including water and food (Gemenne et al. 2014). The film industry and other media 
sources are increasing the understanding of this unwelcomed situation of climate change along with its negative impacts. Movies like "A Day After Tomorrow" or "An Inconvenient Truth" playing a vital role in the process of awareness about this unfortunate situation of climatic variations. It's not the end of story, climate change is impacting the entire global almost equally apart from difference between developed and developing countries regarding the contribution in changing the climate (Nordhaus, 1991; Stern, 2006). Here become very necessary to discuss the role of first world and third world countries with special reference to enhancement and mitigation of climate change. There is huge difference between facts and values regarding the climatic variations and its impacts on less developed countries as compared to developed countries. Pakistan being a developing economy already facing many problems, while catastrophic impacts of climate change further adding fuel to fire. Depressing impacts caused by climate change over the agricultural yield of Pakistan is worrisome (Hussain et.al, 2005). Soil has become saline, sea water is causing floods and putting Pakistani farmers at compromising conditions (Oxfam, 2009). As climate change in contemporary era is also associated directly with the humane security, so the major objective of this research is to observe and to inspect the climatic variations through qualitative content analysis in order to address following research questions.

- What are the impacts of climate change on Pakistan?

- How to control climate change in Pakistan through policy making and what are the major challenges towards it?

- What will be the situation of Climate Change after Corona pandemic?

- What are the proposed solutions to control climate change as a security threat?

The articulation of the climate change as a security threat got momentum since 2003.There is no denying of the fact that climate change is a global issue that poses serious threats to humanity. It has created adverse circumstances for the socioeconomic sector. To be certain, the entire world has observed the detrimental effects of global warming "in the form of extreme weather like storms, cyclones, floods, and droughts. Subsequently, the world presently suffers around 400-500 natural disasters on average in a year, up from 125 in the 1980s"(Global Review, 2007). In short, climate change is a grave issue that has created serious challenges for humanity.

The report of IPCC revealed that the process of reduction and modification positively or negatively affect the productive results of other societal goals related to human health and food security (IPCC, 2014:5). Another report of the IPCC demonstrated that climate change generates results in the form of extreme weather and climate events (IPCC, 2012:5). It is an established fact that climate change is happening around the globe. We have observed an extreme rise in temperature, varying seasons and snowfall patterns, intensifying sea-level, lessening sea-ice, and liquefying glaciers and posing severe threats to the world(Singh \& Singh, 2012: Weitzman, 2009: Leiserowitz, 2005). After observing the whole scenario from future perspective, the entire system of nature is at risk (Walker et al., 2014).Climate 
Change will remain a serious issue despite the measures of international world to restraint greenhouse gas emissions (Wilson, 2006).

\section{Impacts on Pakistan}

A number of countries are at jeopardy due to climate change and this risk is even greater for less developed countries. Due to this grave issue as it is having a negative influence on South Asia, and this region has become more disaster prone (Kekar \& Bhadwal, 2007; Sivakumar \& Sefanski, 2011). Like other regions, South Asia is also observing the negative effects of climate change (Sterrett, 2011). The soft targets of negative changes in environment which are occurring rapidly with the passage of time are poor public of these areas (Morton 2007). In addition, our country is extremely vulnerable to the effects of climatic variations due to its dependency over the agriculture (Wassmann et al., 2009). Pakistan is also included in the list of top 10 most susceptible countries to climate change(Khan \&Samiillah, 2015).

Broadly speaking, climate change is happening rapidly and producing negative impacts on Pakistan. Geologically, Pakistan is situated in area where the influences of climate change are being observed quite seriously (Malik et. al., 2012). "Disasters like floods, droughts, and other natural calamities" are main examples of climate changes in Pakistan (Banoori, 2012). There is huge economic, social and environmental impact due to this climatic disastrous. Statistics of 2010 floods shows the catastrophic impacts over the 20 million lives of the people who lost their home, got wounded, and got missing (Kurosaki et.al. 2011). Similarly, another flood in 2012 brought disaster in Pakistan (Germanwatch, 2014). Income, shelter, food and security are at risk in Pakistan due to climate change (Aftab\& Hickey, 2010). Keeping in view the harsh facts, Pakistani state needs to take serious steps to tackle the negative influence of climate change. No doubt, this issue has got a particular attention of the official authorities who also consider it a sensitive and serious issue (Rasul et al. 2011). Pakistan has taken various steps such as formulation of climate policy and action plans. In Pakistan, first climate change policy was enforced in 2012. The enforcement of the National Climate Change Policy (NCCP) was indeed a significant development. NCCP suggests more than 120 policy measures covering different areas.

Despite contributing a very minuscule amount of greenhouse gases emission the Pakistan is among the most affected countries by climate change in following ways

- It is expected that melting of glacier in the Himalayas will increase in coming time which reciprocally increase the rate of flooding in Pakistan.

- Availability of fresh water for life activities is predicted to decrease due to which life will be at risk and population will face severe circumstances. 
- Communities at the border of the Arabian Sea in the south of Pakistan is at maximum risk due to increased risk of flooding due to climate change.

- Pakistan economy is highly based on agriculture. Due to challenges posed by climate change the yield of the crops are at risk which directly influence the livelihood of the population and creating many other social problems like poverty, and urbanization etc.

- It is projected that due to climate issue diseases like Cholera in the coastal Areas of Pakistan are getting momentum.

- Climate change also enhancing social inequalities in the Pakistan due to depletion of resources and economic injuries. Economic inequalities, displacement of peoples and conflictive situation will further increase. (LEAD,n.d.)

As discussed earlier, Pakistan has observed a tremendous human and economic loss due to deadly flooding in Pakistan. People had to leave their shelters to secure their lives. Their houses were destroyed due to this natural disaster. At present, we have entered in a new phase. Almost all countries have recorded an extreme rise in terms of global temperature. Pakistan also observed extreme cold as prime minister directed concerned authorities to provide temporary shelter to homeless. First time in the history of Pakistan, shelter houses were established. Now, we have entered in a new year. It is hoped that international world especially Pakistan will take serious steps on priority basis to tackle the haphazard of this issue. The way the climatic conditions globally are altering, there are massive chances that it would have drastic consequences on Pakistan in the form of severe conditions like floods, dearth and hurricane, wearing of coastlines and decrease agricultural growth. According to Global Climate Risk Index of 2017, Pakistan is rated seventh all over the world with recoded US\$3.8 billion (PPP) damages between 1996 and 2015, because of climatic alterations (UNDP, 2018).

\section{Outcomes on Pakistan Economy}

The nature of Pakistan's economy is agro-based, and this is where these sudden worldwide environment changes are a major threat to Pakistan's agriculture sector. Currently, the global reports are indicating that the nation is placed 12th among the countries, which are under serious threat due to these rapid weather changes. The varying degree of temperature rise and modifications in precipitation are extremely vulnerable for Pakistan, and there are great chances that it would severely damage country's water resources, forests and agriculture, mostly on which the living and economy depends. Particularly, the fast temperature rise is expected to change the bio-physical correlation of fisheries, livestock, crops and forests, by reducing their growth periods, alteration in species patterns, variation in water necessities, amplification of pests and diseases, and intensification in thermal and moisture stresses. As far as the agriculture sector and natural resources are concerned, the climatic alterations effects would differ due to varied agro-ecological areas. The western mountainous part that is dry in nature, the quick temperature rise could increase the course of de-glaciations, which would massively affect the water 
resources that are extraordinarily used for agriculture and energy production. At the moment, theses western hilly regions are facing grave threat because of different natural and human activities, and as a result, the ecological destruction in these areas are continuously happening (Ullah, 2017).

For a country, it is essential that their agriculture sector is working properly, in order to augment food protection, living quality and swift economic progress. The studies from developing countries reflect that agriculture production holds a huge share in their gross domestic product (GDP). Therefore, the economic progress is inevitable without strengthening the agricultural productivity. The Economic Survey of Pakistan (2011-12) has clearly highlighted this fact that Pakistan's chief natural resource is arable land, and 21 percent in GDP is what agriculture segment's contribution accounts for. In addition to it, 45 percent work force is currently involved in country's agriculture production, and 18 percent exports share is what in total it makes off. It now has become imperative to examine the effect of environmental change on main crops in Pakistan, keeping in view the importance agriculture sector holds to country's economy, and how temperature and precipitation are making a disturbing impact on it (Siddiqui et al, 2012).

Also, Pakistan's industrial sector is crucially dependent on agriculture growth, which is a direct threat to this segment as well; resulting in negative consequences to country's economy (Zafar, 2015). Without a doubt, climatic alteration is bound to have effects on sustainable food and energy production. It results in direct and indirect consequences on energy and food security, through grave danger to food manufacturing and the final product quality. Then, the natural food and energy resources are continuously depleting because of natural calamities, happening due to these sudden environmental changes. Unfortunately, Pakistan over the years has faced huge economic losses to infrastructure and the agriculture sector due to floods. The 2010 flooding in particular resulted in US\$ 9.6 billion damages, and five successive floods since 2010 have caused more than US $\$ 25$ billion of economic setback; the sectors that directly faced losses in it were public infrastructure, health, irrigation, agriculture and education infrastructure. Cotton manufacturing, which holds great importance to Pakistan's economy as bulk of country's industries are associated with it, has extremely suffered in this whole situation. The urbanization and population rise along with extreme environmental challenges are in addition causing security issues, and the United Nations have already predicted that in 2025, an increase in world population is likely from 7.2 billion currently to 8.1 billion. Pakistan, similarly is witnessing this gigantic rise in population, and how climatic conditions parallel to it are having negative impacts on country's economy. Moreover, it has been observed that continuous heat wave patterns and extreme rise in temperature are having drastic consequences on food production and energy sustainability, which has extraordinarily increased electricity consumption than the production capacity due to warm weather, eventually resulting in prices increase because of extra utilization than production. Hence, it is clearly visible that the global change in climate patterns are directly linked with 
socio-economic problems and sustainable and long term strategies are required at both regional and national levels for strong economic growth (Zahra, \&Batool, 2016). There is an important aspect to be looked upon is that these climate change consequences vary in terms of its impact; the developing countries will be more vulnerable to these changes (Nordhaus, 1991; Stern, 2006), as it would have direct impact on crop production, water resources, ecosystems and human health (Akram, $\&$ Hamid, 2015). The climate-sensitive segments in developing countries are upon which there large population depend, and they lack adaptive capacity mechanisms through which they can adapt or cope in situations like these. Regardless of this fact that they have very narrow role in Greenhouse Gases (GHGs) emission, the developing countries have to bear the expenses to cope against them (Sathaye, 2006), and due to lack in resources, the masses ultimately are the one that are being continuously exposed to this danger (Parry et al., 2007).

\section{Guidelines at National Level Policies and Strategic Papers}

In environmental change context, Pakistan in the past years have made concrete planning and devised many policy initiatives, and significantly, the nation is gearing for an official climate change approach. Prominent examples of it are the submission of National Communication to the UNFCCC in 2003, and the foundation of Prime Minister's Committee on Climate Change, that basically is a group for annual basis monitoring of weather change patterns, and giving policy guidelines. Then, the Planning Commission, a group given the task to formulate National Plans for nation's primary economic sectors; in October 2008, made a Task Force on Climate Change with principle responsibility to prepare a strong climate change policy. In 2010, the Task Force came with its final report, which sketched Pakistan's at present approach to tackle the environment change problem from both adaptation and mitigation point of views, and it also suggested important adaptation actions in major socio-economic areas (GOP, 2010). Adding to it were different approaches for various sectors; prominent of them were National Water Policy, National Environmental Policy, National Conservation Strategy and National Forest Policy (draft), which also highlighted the possible consequences of climate change.

To Pakistan's credit, they have shown endorsement to all international steps taken regarding climate change; an apt example of it is their approval to all declarations of SAARC (South Asian Association for Regional Cooperation) on climate change, which includes the 2010 Thimphu Declaration. Also, there is a strong opinion that Pakistan history's most severe flood of 2010 has impelled the country's policy makers to devise a national course of action concerning climate change. For this purpose, Pakistan are making concrete efforts to acquire funds from the international sources, primarily from the United Nations (UN). One instance in this perspective is the September 2010 meeting at UN General Assembly, when Pakistan's Foreign Minister stated, “Climate change, with all its severity and unpredictability, has become a reality for 170 million Pakistanis. The present situation in Pakistan reconfirms our extreme vulnerability to the adverse impacts of climate change." Most importantly, Pakistan are lobbying to emphasize on this 
expression "particularly vulnerable developing countries" in UN agreements that are to be signed in future (Khan, 2010).

In 2018 government of Pakistan with the help of UNDP launched a project of US\$37 million for the benefits of the people who were extremely affected by the challenges of climate change. Green Climate Fund (GCF) is five year project for the most vulnerable communities of Gilgit-Baltistan and KPK. The purpose of this project is to help the Pakistan to achieve its objectives of sustainable development goals and to end poverty and hunger till 2030. More than fifty percent beneficiaries of the projects are the women community of Pakistan, which will lead to help the removal of gender inequalities faced by Pakistan. (UNDP, 2018).

\section{Climate Change after Corona Pandemic}

Corona virus which hits the planet earth in the end of year 2019 starting from Wuhan set a situation of emergency at national as well as of international level. The pandemic posed a severe damage to the national as well as international economy. Along with its negative hits, environmental scholars witnessing some positive impacts of it on the environment due lockdown of activities. Fred Pearce in his article "After the Corona virus, Two Sharply Divergent Paths on Climate" raised the question about the status of climate change in post corona virus world. (Pearce, 2020). Two divergent views i.e. optimistic and pessimistic view is getting momentum in this regard. Some scholars are hopeful that after corona virus it will be easy for the policy makers and environmentalist to tackle environmental challenges because a recovery has been observed in climate change due to lockdown of the world during the pandemic. This optimistic view is also supported by Bill Gate that after corona virus world will be prepared to share the responsibility of the climate change to avoid future lethal conditions. Glen Peters "Research Director, Center for International Climate and Environment Research - Oslo" said that there is close connection between CONVID- 19 and carbon dioxide emission. He further said that $\mathrm{CO} 2$ emission has been reduced surprisingly due to the shutdown caused by CONVID-19 in the world. This slowdown of CO2 emission was not even observed during economic financial crisis of 2008 (Peters, 2020).

While on the other hand pessimistic view is also considerable due to its validity in the past. As the virus has creates economic crisis in the world so in post corona world, countries will be more prone towards stabilizing their economies rather than to worry about future generation and saving them from climate emergency. The future inclination of the world to save their economies will put aside the climate issue for years which reciprocally affect the planet. Pessimists are predicting the leap backward rather than forward after CONVID-19. According to pessimistic view Governments will adopt desperate measures to stabilize their economies and for this purpose old energy intensives and fossil fuels utilization for industries will got momentum. In this way these steps will give a green signal to the pessimistic view of climate challenges and CO2 emission. (Pearce, 2020). 
Government of Imran khan in Pakistan who already got strained economy faced a severe setback to the economy of Pakistan due to the pandemic. The initial assessment report shared by Islamabad showed the loss in economy due to CONVID-19 at the gigantic figure of 2.5 trillion (Haider, 2020). While taking into account the impacts of climate change over Pakistan it is already clear that Pakistan share in carbon dioxide emission is minuscule while Pakistan facing gigantic impacts of climate change over it in the form of floods, heat waves, drought, and melting of glaciers etc. while applying two different views on post corona virus world given by Fred Pearce it is clear that chances of Pakistan to fall under pessimistic view is maximum. While talking to UN Climate Action summit in 2019 Imran khan said that Pakistan taking into account the reduction of emission of greenhouse gases in order to tackle challenges posed by climate change. (Khan, 2019) but after post corona virus Pakistan will try to stabilize its dwindling economy due to which chances of putting climate change at second priority is maximum, Which according to pessimistic view a green signal to climatic problems. Apart from it Pakistan will be among the most vulnerable countries to climate hazards when after corona virus world desperately start to save their economies on the expense of climate change by using energy intensives and fossil fuel industrialization.

\section{Strategies to cope with Climate Change}

- Climate change is a serious issue in contemporary era. To avoid its hazards it is essential to communicate and to give awareness to the public. People are not giving enough importance to climate change. By using media strategies it should be informed to the masses that there is risk in "do nothing" options. Targeted audiences for this purpose include: General public, Farmers, Fisher Folk, Vulnerable communities, youth, disable people, school going children, Policy Makers, Opinion leaders, Researchers, Civil Servants and Business community. Communicating tools for this purpose includes reading material, promotional material, Phone call, SMS, face to face and personal talk, online, audio visuals, documentaries, talk shows, Music and Curricula etc. (ESPACE, n.d.)

- Competent policies regarding mitigation and adaptations should be adopted. A community should be created which gave information regarding the mitigation and adaptation of the climate change. Quality information should be used for this purpose.

- Toxic emission is major reason of climate change. There must be cut down to the use of such vehicles. Behavior to use public transport should be adopted rather than to use private transportation. Hybrid vehicles have lower rate of emission, so these cars should be used. (Shahzad, 2015).

- Use of fossil fuels should be discouraged as these are the major contributors of degeneration of the environment. Instead of it alternative energy resources such as wind, bio, hydro and solar energy should be used. Renewable source of energy is best solution to the climate challenges. (Shahzad, 2015).

- Good governance is at the center of the issue, all the possible solution is only workable if government will frame and design implementable and competent 
decision making. Policies regarding adaptation and mitigation should be framed on priorities bases and should be implemented in letter and spirit

- Construction of dams to assess and address the additional water problem in Pakistan is essential along with taking action to enhance the life of existing storage facilities (GOP, 2012).

- After CONVID-19 it is essential to change the life style of people because sudden use of vehicles and high rate economic activities can lead he world for another disasters in the form of climate explosion. For this purpose Governments needs to use renewable source of energy to stabilize their economies which got hit by the corona virus. A moderate and mutual approach at national and international level should be adopted.

\section{Conclusion}

Developing countries like Pakistan are highly affected by the perils of climate change despite sharing little amount of greenhouse gasses as compared to the developed nations. Corona virus will further worsened the situation because economic damages caused by the pandemic will be at the first priority in post corona times rather than climate change. Recovery caused by shutdown of the world will again get green Signal of climate change due to rapid industrial work after the corona virus. Pakistan will be skeptical to the challenges of climate change because its economy is highly dependent on Agriculture. The effects of climate change over Pakistan can be mitigated if above mentioned recommendations can be adopted in letter and spirit. Adaptation and mitigation policies along with good governance would be helpful to cope the challenge of climate change. In 2018 a five-year plan was launched by Prime Minister of Pakistan Imran khan, in this plan extensive tree plantation campaign was started to combat rising temperature, floods and other climate related events. This is well planned program which should be adopted at school, college, university and at public and private level.

\section{References}


Aftab E, Hickey GM (2010). Forest administration challenges in Pakistan: the case of the Patriata reserved forest and the new Murree development. Int For Rev 12:97105

Akram, N., \& Hamid, A. (2015). Climate change: A threat to the economic growth of Pakistan. Progress in Development Studies, 15(1), 73-86.

Banoori W (2012). Pakistan: climate report. http://www.thefrontie rpost.com/article/163613.

Field, C. B., Barros, V., Stocker, T., Qin, D., Dokken, D., Ebi, K.,\&Tignor, M. (2012). IPCC, 2012: Managing the risks of extreme events and disasters to advance climate change adaptation. A special report of Working Groups I and II of the Intergovernmental Panel on Climate Change. Cambridge University Press, Cambridge, UK, and New York, NY, USA, 30(11), 7575-7613.

Gemenne, F., Barnett, J., Adger, W. N., \&Dabelko, G. D. (2014). Climate and security: evidence, emerging risks, and a new agenda. scholar.google.com.pk/scholar?hl=en\&as_sdt $=0 \% 2 \mathrm{C} 5 \& a s \_v i s=1 \& q=\% 28 \mathrm{~W} .+\mathrm{Nei}$ $1+$ Adger $\% 2 C+2014 \% 29 .+$ climate+change $+\& b \operatorname{tnG}$

Germanwatch (2014). Global climate change risk index. Germanwatch, Berlin

GOP, (2010). Task Force on Climate Change: Final Report. Planning Commission. Government of Pakistan

GOP, (2012). Ministry of Climate Change: National Climate Change Policy. Government of Pakistan

Hussain, S. Goheer, A., \& Sultana, H. (2005). Sensitivity of wheat yield to climate change in Punjab using DSSAT-based CERES- Wheat Simulation Model. Global Change Perspective in Pakistan, Asianics Agro Development International.

IPCC (2014). Summary for Policymakers. In: climate Change 2014: impacts, Adaptations and vulnerability. Contribution of working Group II to the Fifth Assessment report of the intergovernmental Panel on Climate Change.

Kelkar, U. \& Bhadwal, S (2007) South Asian regional study on climate change impacts and adaptation: Implications for human development. Human development report, United Nations Development Programme

Khan, M. A. \& Samiullah, M. (2015). Financing for disaster risk reduction in Pakistan. In: Rehman AU et al (eds) Disaster risk reduction approaches in Pakistan, disaster risk reduction. Springer, Japan

Khan, R.S. (2010). Flood-hit Pakistan seeks priority access to climate change aid. AlertNet.http://www.alertnet.org/db/an_art/60167/2010/08/28-122928-1.htm. 
Kurosaki T, Khan H, Shah MK, Tahir M (2011). Natural disasters, relief aid, and household vulnerability in Pakistan: evidence from a pilot survey in Khyber Pakhtunkhwa. PRIMCED discussion paper series 12, Hitotsubashi University

Leiserowitz AA (2005). American risk perceptions: is climate change dangerous? Risk Anal 25:1433-1442

Malik, S. M. Awan, H. \& Khan, N. (2012) Mapping vulnerability to climate change and its repercussion on human health in Pakistan. Glob Health, 2012(8):31

Maskrey, A., Buescher, G., Peduzzi, P., \&Schaerpf, C. (2007). Disaster risk reduction: 2007 global review. Consultation edition. Prepared for the global platform for disaster risk reduction first session, Geneva, Switzerland, 5-7.

Nordhaus, W.D. (1991). To slow or not to slow: The economics of the greenhouse effect. The Economic Journal, 101, 920-37

OXFAM. (2009). Climate change, poverty and environ-mental crisis in the disaster prone areas of Pakistan. OXFAM.

Parry, M., Canziani, O., Palutikof, J., Linden, P.V., \& Hanson, C. (2007). Climate change 2007: Impacts, adaptation and vulnerability. Contribution of Working Group II to the Fourth Assessment Report of the Intergovernmental Panel on Climate Change (IPCC). Cambridge University Press, p. 976

Pearce, F. (2020). After the Coronavirus, Two Sharply Divergent Paths on Climate" Yale school of forestry and environmental studies. https://e360.yale.edu/features/afterthe-coronavirus-two-sharply-divergent-paths-on-climate

Peters,G. (2020). How changes brought on by coronavirus could help tackle climate change. https:/ / theconversation.com/how-changes-brought-on-by-coronavirus-couldhelp-tackle-climate-change-133509.

Rasul, G. Chaudhry, Q. Mahmood, A. Hyder, K. \& Dahe, Q. (2011). Glaciers and glacial lakes under changing climate in Pakistan. Pak J Meteorol, 8(15):1-11

Sathaye, J. Shukla, P.R. \& Ravindranath, N.H. (2006). Climate change, sustainable development and India: Global and national concerns. Current Science, 90, 31425.

Shahzad, U., \& August, R. (2015). Global warming: Causes, effects and solutions. Durreesamin Journal, 1(4).

Siddiqui, R., Samad, G., Nasir, M., \&Jalil, H. H. (2012). The impact of climate change on major agricultural crops: evidence from Punjab, Pakistan. The Pakistan Development Review, 261-274. 
Singh, B. R. Singh, O. (2012). Study of impacts of global warming on climate change: rise in sea level and disaster frequency. In: Singh BR (ed) Global warming - impacts and future perspective. http://www.intechopen .com/books/global-warmingimpacts-and-future-perspective. Accessed Aug 2017

Sivakumar, M. V. K. \& Stefanski, R. (2011). Climate change in South Asia. In: Lal R, Sivakumar MVK, Faiz SMA, Mustafzur-Rahman AHM, Islam KR (eds) Climate change and food security in South Asia. Springer, Netherlands, pp 13-30

Stern, N. (2006). The economics of climate change, The Stern review. Cambridge University Press.

Sterrett, C. (2011). Review of climate change adaptation practices in South Asia. Oxfam research reports, Climate Concern, Australia

Ullah, S. (2017). Climate change impact on agriculture of Pakistan-A leading agent to food security. International Journal of Environmental Sciences \& Natural Resources, $6(3), 76-79$.

UNDP (2018). Provincial launch event for a US\$37 million UNDP-supported GLOF-II projecthttps://www.pk.undp.org/content/pakistan/en/home/presscenter/pres sreleases/2018/ provincial-launch-event-for-a-us-37-million-undp-supportedglof-.html

Walker, B. J. Adger, W. N. Russel, D. (2014). Institutional barriers to climate change adaptation in decentralised governance structures: transport planning in England. Urban Study 52(12):2250-2266

Wassmann, R. Jagadish, S. Sumfeth, K. Pathak, H. Howell, G. Ismail, A. Serraj, R. Redona, E. Singh, R. \& Heuer, S. (2009). Chapter 3 regional vulnerability of climate change impacts on asian rice production and scope for adaptation. In: Advances in agronomy, vol 102. Academic Press, pp 91-133

Weitzman, M. L. (2009). On modeling and interpreting the economics of catastrophic climate change. Rev Econ Stat, 91(1):1-19

Wilson, E. (2006). Adapting to climate change at the local level: the spatial planning response. Local Environ 11(6):609-662

Zafar, F., Ahmad, F. (2015). Climate change and agriculture, Pakistan Today. http://www.pakissan.com/english/issues/climate-change-and-agriculture.sh.

Zahra, S. Batool, M. \& Bashir, Q.A. (2016). Impact of global climate change on economy of Pakistan: how to ensure sustainable food and energy production. http://medcraveonline.com/APAR/APAR-05-00177.pdf 
